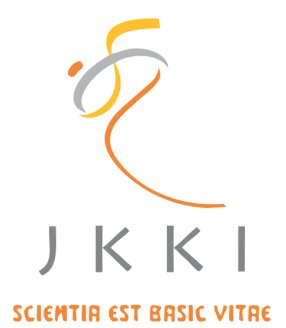

Jurnal Kedokteran dan Kesehatan Indonesia

Indonesian Journal of Medicine and Health

Journal homepage: https://journal.uii.ac.id/JKKI

\title{
Pathophysiological and clinical findings of Covid-19 virus infection in respiratory system: A anatomist's view point
}

Takashi Yashiro ${ }^{1,2}$, Endin Nokik Stujanna*1, Leli Hesti Indriyati ${ }^{1}$, Wawang Setiawan Sukarya ${ }^{1}$

${ }^{1}$ Faculty of Medicine, Universitas Muhammadiyah Prof.DR. Hamka, City of South Jakarta, Indonesia. ${ }_{2}^{2}$ Jichi Medical University School of Medicine, Japan

\begin{tabular}{l}
\hline ARTICLE INF O \\
\hline *Corresponding author: \\
endin_stujanna@uhamka.ac.id \\
\hline DOI:10.20885/JKKI.Vol11.Iss2.art1 \\
\hline Copyright @2020 Authors. \\
This is an open access article \\
distributed under the terms \\
of the Creative Commons At- \\
tribution-NonCommercial 4.0 \\
International Licence (http:// \\
creativecommons.org/licences/ \\
by-nc/4.0/).
\end{tabular}

\section{GUEST EDITORIAL}

A new corona virus, Covid-19, is expanding, and this world is facing the pandemic. ${ }^{1,2}$ There are many patients who have been infected 1 by this virus. While some experience no symptoms, some show upper respiratory infection symptoms either in moderate or in serious symptoms. Thus, the biggest problem is that there are many patients who fall into respiratory dysfunction and die. ${ }^{3}$

Combined binding and activation mechanism, allow the virus to get into host cells. It's "spike" protein binds to angiotensin-converting enzyme 2 (ACE2) of goblet cells (in the nasal), type II pneumocytes (in the lung), and enterocytes (in the intestine). In addition, an enzyme, called Transmembrane protease serine2 (TMPRSS2), helps the activation of Covid-19 virus. ${ }^{4,5}$

Several initial symptoms of the Covid-19 virus infection can be found in the respiratory system. Fever and cough are seen in 60-90\% cases. Common cold symptoms, like nasal discharge, cough, fever, and sore throat can be found. Nasal discharge is caused by goblet cell activation. If goblet cells are disabled, and the mucus is not secreted, this symptom often cannot be seen. ${ }^{6}$ If an upper airway disorder occurs, the virus is carried to the whole body that can infect others such as digestive tracts.

Infected type II pneumocytes by Covid-19 virus can cause pneumonia. A relatively early period of Covid-19 can cause interstitial pneumonia in almost half of asymptomatic patients (CT scan examinations). This condition is affected by Covid-19 virus infection in type II pneumocytes. Type II pneumocytes, also called large great alveolar cells, have a very important rules in the respiration. It produces pulmonary surfactants and progenitor/stem cells for type I pneumocytes. When type II pneumocytes become compromised, pulmonary surfactant cannot be secreted, and symptoms of respiratory distress syndrome (RDS) may occur. Furthermore, if type II cells are selectively attacked by the virus, replenishment of type I cells and additional structural recovery of alveolar septa may be difficult. Therefore, a prognosis of life can be adversely affected. ${ }^{7}$

KL- 6 is known as a marker that indicates a progress of interstitial pneumonia (pneumonitis), and it is often clinically applied. The KL- 6 can be found in type II pneumocytes cytoplasm. The increase of KL-16 reflects the number of type II cells. The rise of KL-6 is not so high with Covid-19 infection pneumonia. In a report by Kurahsima et.al, KL-6 is $163.5 \mathrm{U} / \mathrm{ml}$ in asymptomatic and mild cases, $217.3 \mathrm{U} / \mathrm{ml}$ in cases with pneumonia, and $211.6,8 \mathrm{U} / \mathrm{ml}$ in severe cases (it is more than $1.000 \mathrm{U} / \mathrm{mL}$ with normal interstitial pneumonia). These results seem to reveal that damages of alveolar septa structure in Covid-19 infection are not easy to regenerate.

Although infected patients are treated with various conventional treatments, including use of Extracorporeal Membrane Oxygenation (ECMO) to improve the infection itself, regeneration of alveolar 
septa is not easy to develop. In addition, a steroid treatment is suggested to be not effective for this novel pneumonia. This is because this pneumonia is not principally caused by immunoreaction disorder but by selective type II pneumocytes damaged by Covid-19. The rapid progress of respiratory symptoms and dyspnoea symptoms may be influenced by reduction of pulmonary surfactants synthesized and released from Type II cells. ${ }^{8}$

\section{CONFLICT OF INTERESTS}

The authors have declared that no competing interests and financial disclosures exist.

\section{ACKNOWLEDGEMENTS}

The Authors would like to thank to Dr. dr. Gea Pandhita, Sp.S, M.Kes and Mr. Fauzano Rahmatul Mukhlisisn, S.Hum. for technical assistance in this paper.

\section{REFERENCES}

1. Ahmed H, Allaf M, Elghazaly H. COVID-19 and medical. The Lancet Infectious Disease. 2020;https://doi.org/10.1016/S1473-3099(20)30226-7.

2. Longhurst GJ, Stone DM, Dulohery K, Scully D, Campbell T, Smith CF. Strength, weakness, opportunity, threat (SWOT) analysis of the adaptations to anatomical education in the United Kingdom and Republic of Ireland in response to the COVID-19 pandemic. Anatomical Science Education. 2020;0-2.

3. YC Li, WZ Bai, Tsutomu Hashikawa. The neuroinvasive potential of SARS-CoV2 may play a role in the respiratory failure of COVID-19 patients. Journal of Medical Virology.2020;92:552-555.

4. Verdecchia Paolo, Cavallini Claudio, Spanevello Antonio, Angeli Fabio. The pivotal link between ACE2 deficiency and SARS-CoV-2 infection. European Journal of Internal Medicine. 2020;76: 14-20.

5. Ziegler CGK, Allon SJ, Nyquist SK, Mbano IM, Miao VN, Tzouanas CN, et al. SARS-CoV-2 Receptor ACE2 is an interferon-stimulated gene in human airway epithelial cells and is detected in specific cell subsets across tissues. Cell. 2020;181:1016-1035.

6. Kazuyoshi Kurashima, Naho Kagiyama, Takashi Ishiguro, Keisuke Kasuga, Yasuhiro Morimoto, Ryota Ozawa, Kenji Takano, Taisuke Isono, Takashi Nishida, Eriko Kawate, Chiaki Hosoda, Yoichi Kobayashi, Yotaro Takaku, Noboru Takayanagi TY. Risk factors for the severe COVID-19 pneumonia. The Japanese Association for Infectious Disease. 2020;1-7.

7. Shohei Inui, Akira Fujikawa, Motoyuki Jitsu, Naoaki Kunishima, Sadahiro Watanabe, Yuhi Suzuki, Satoshi Umeda, Yasuhide Uwabe. Chest CT findings in cases from the cruise ship "diamond princess" with coronavirus disease 2019 (COVID-19). Radiology. 2020;2(2):1-17.

8. Sznitman J. New hope for coronavirus patients with acute respiratory distress syndrome American Technion Society. Israel Institute of Technology. 2020. https://ats.org/our-impact/ donor-spotlight-lewis-and-joan-lowenstein-foundation/ 